\title{
INTERNATIONAL CIVIL PROCEDURE IN INDONESIA
}

\author{
Sudargo Gautama*
}

\section{GENERAL CONTEXT}

\subsection{Introduction}

More than half a century after Independence, civil law and civil procedure law in Indonesia are still under the influence of the Dutch legal system. As a colony of the Netherlands, the Netherlands Indies in its legal system in civil matters closely followed the law and prevailing doctrines of the 'motherland' under the so-called concordance principle. ${ }^{1}$ This principle was embodied in Article 131(2)(a) of the colonial quasi Constitution. ${ }^{2}$ It was, of course, abandoned after independence. Yet, even in today's legal practice Dutch judicial decisions and Dutch scholarly opinions and interpretations are still widely followed. ${ }^{3}$

While the concordance principle applied to the part of the law that was of European origin, the colonial legal regime was simultaneously based on a system of different substantive and procedural civil law for various racially defined sub-divisions of the population and for different culturally defined parts of the country. This feature of the system was anchored in the notorious Article 163 of the above quasi Constitution. Although the legal distinctions along racial lines $^{4}$ were immediately abolished after independence as far as public law was concerned, this was not necessarily the case with regard to private law. ${ }^{5}$

\footnotetext{
* Professor of Conflict of Laws, University of Indonesia, Jakarta.

${ }^{1}$ On this principle, see S. GAUTAMA and R.N. HORNICK, An Introduction to Indonesian Law (Alumni Publ., Bandung, 4th printing, 1983), and also S. GAUTAMA, Indonesian Business Law (Citra Aditya Bhakti Publ., Bandung, 1995) 10 et seq.

${ }^{2}$ In Dutch Indische Staatsregeling; also 'Constitution of the Indies'. Netherlands Act of 23 June 1925, Netherlands Indies State Gazette (NISG) (1925) No. 415.

${ }^{3}$ See the proceedings in Kartika Thahir $v$. Pertamina, Singapore Law Reports (1993 No. 1) 735, where the issue of to what extent Indonesian case law and legal practice is still being influenced by Dutch case law and legal learning was hotly debated.

${ }^{4}$ The law distinguished between 'Europeans', 'Natives' (Dutch: Inlanders) and 'Foreign Orientals'. Europeans comprised Dutch citizens, other persons of European stock, Japanese nationals, and all others who in their native country were subjected to family laws essentially similar to Dutch law, such as the Thais and the Turks, and the children of Europeans born in Indonesia and their descendants. Indigenous people or Natives included the main Indonesian population except those who were legally 'equated' with Europeans or women who had moved to the category of Europeans by marriage. The Foreign Orientals comprised all those not belonging to either of the two previous
} 
In order to avoid a legal vacuum after independence, the Constitution contains a provision on the validity and applicability of the law, including the Netherlands Indies codes of law, as it existed at the time independence was attained, i.e. on 17 August 1945. Article II of the Transitory Provisions of the Constitution stipulated, inter alia, that all existing regulations were to remain in force as far as they were not replaced in accordance with the Constitution. The application of this provision later underwent the impact of another instrument that was promulgated shortly afterwards. On 10 October 1945 , barely two months after the declaration of independence, Government Regulation 1945 No. 2 was proclaimed. ${ }^{6}$ It essentially repeated the above transitory rule but added the proviso that existing regulations would only remain in force "insofar as they are not contrary to the Constitution itself". Because of this last sub-sentence the transitory regulation was later interpreted as prescribing the abolition of the existing law unless it was not contrary to the 1945 Constitution. If found to be contrary to that Constitution, it should be considered invalid even though no new legislation had yet been enacted to replace it. ${ }^{7}$

In practice it has not always been entirely clear which rules were abolished or altered since independence. This applies also to the ('European') Civil Code ${ }^{8}$ and Code of Civil Procedure ${ }^{9}$ and is, among other things, caused by the ambiguous interpretation and application of the transitory provisions relating to the law at the time of the attainment of independence. Another reason for this ambiguity is that, in introducing new law, the Indonesian legislature frequently does not clearly identify which parts of the existing law shall be deemed to be

categories.

${ }^{5}$ The distinction was upheld in court practice as late as the 1970s: in its Decision of 25 August 1971 (case No. 268K/Sip/1971) the Supreme Court held "that the relationship between plaintiff and defendant is one governed by the law on internal inter-legal relationships [hubungan hukum antar tata-hukum intern], to which Western law [emphasis added] is applicable, as the defendant [an indigenous Indonesian] should be deemed, in accordance with relevant precedent, to have voluntarily entered into the legal sphere of the other party [an Indonesian of Chinese descent, and thus subject to the 'European' civil law]. See SUDARgo GAUTAMA, Himpunan yurisprudensi Indonesia yang penting untuk praktek sehari-hari - Landmark decisions [Collection of Important Indonesian Court Decisions for Daily Legal Practice - Landmark decisions], Vol. 9 (1994) case No. 2 .

${ }^{6}$ KoESNODIPRODJO (ed.), 1 Himpunan Undang2, Peraturan2, Penetapan2 Pemerintah Republik Indonesia [Collection of Acts, Regulations and Decisions of the Government of the Republic of Indonesia] p. 34.

${ }^{7}$ In 1962, Minister of Justice SAHARDJO, in line with the 'revolutionary approach', suggested at a session of the National Law Development Institute that the (European) civil and commercial codes should no longer be regarded as proper codes of law but merely as 'law books' or 'commentaries', comparable to the 'restatements' in the US. See GAUTAMA and HORNICK, op. cit n. 1 p. 185 et seq.

${ }^{8}$ NISG 1847 No. 23.

${ }^{9}$ The so-called (Dutch) Reglement op de Rechtsvordering (hereinafter RV), NISG 1847 No. 52. 
abolished, but rather confines itself to the phrase "earlier regulations contrary to the new law are no longer in force". ${ }^{10}$

\subsection{The judicial system}

Under the 1945 Constitution judicial power is vested in the Supreme Court and other judicial organs as determined by law. ${ }^{11}$ The Basic Law on Judicial Power ${ }^{12}$ mentions four branches of the judiciary: general courts, religious courts, military courts and administrative courts. For practical purposes only the first branch mentioned will be dealt with in the present paper.

The 'Pengadilan Negeri' (hereinafter: PN) or 'Country Court' or District Court is the court of first instance. There is a PN in every 'second degree autonomous region' ${ }^{13}$ PNs are created by the Minister of Justice with the consent of the Supreme Court. Although according to the text of the law the $\mathrm{PN}$ is a panel court requiring at least three judges for taking valid decisions, it often acts as a single-judge court due to lack of qualified personnel. ${ }^{14}$

Before the Japanese occupation during World War II the prevailing racially based legal pluralism did not only refer to the substantive law but to the competence of the courts and the law of procedure as well. According to the socalled 'dualist' system there were separate categories of state courts for those who were classified legally as Europeans and so-called Foreign Orientals on the one hand, and for the indigenous Indonesians on the other. ${ }^{15}$ The PN essentially replaced the pre-war first-instance state courts for the indigenous population (in Dutch: Landraad).

The 'Pengadilan Tinggi' or High Court is the court of appeal. In civil cases appeal to the High Court is open provided the claim is more than 100 Rupiah, which is a nominal amount. ${ }^{16}$

The 'Mahkamah Agung' or Supreme Court is the highest court of the country. Decisions of the High Court may be brought before the Supreme Court for appeal in cassation. Examination at this stage is confined to the legal aspects of the case. Besides, the Supreme Court is entitled to start a special

\footnotetext{
${ }^{10}$ By way of example reference may be made to the discussions on this issue in connection with the introduction of the Basic Agrarian Act in 1960. See S. GAUTAMA, Tafsiran Undang ${ }^{2}$ Pokok Agraria [Interpretation of the Basic Agrarian Act] (Citra Aditya Bakti publ., Bandung, 9th ed., 1993); S. GaUTAMA, Indonesian Business Law, ch. IV 'Land Law'. Art. 58 of the Act provided that all earlier law, whether written or unwritten, that was not explicitly revoked, would continue to be in force to the extent that it was not contrary to the spirit and content of the Act.

${ }^{11}$ Constitution, Art. 24.

${ }^{12}$ Lembaran Negara [(Indonesian) State Gazette; hereafter LN] 1970 No. 19.

${ }^{13}$ In Indonesian: Daerah Swatantra Tingkat Kedua or Kabupaten. Constitution, Art. 18; Law No. 1/1957, LN 1957 No. 6.

${ }^{14}$ This is especially the case in smaller cities.

${ }^{15}$ There were also indigenous courts (in Dutch: inheemse rechtbanken) with limited jurisdiction.

${ }^{16}$ The present (end of 1996) rate is $\mathrm{Rp} 2,300$ to 1 US dollar.
} 
kind of revision procedure by which it, by way of court of last instance, scrutinizes cases of blatant error, fraud, corruption or collusion of judges in a certain case, and the emergence of new facts or evidence which were not known at the time of the original decision and which are of such a nature that, had the court rendering the decision known them, it would certainly not have rendered such a decision. Further, the Supreme Court has jurisdiction over disputes on competence between different branches of courts. Lastly, whenever parties have not agreed about the finality of an arbitral award, an appeal is open directly to the Supreme Court. ${ }^{17}$

\subsection{The sources}

Reference has already been made to the pre-war 'dualist' court system. Accordingly, there was a rather complete though outdated Code of Civil Procedure (RV). It dated from 1847 and essentially was a copy of the corresponding Code in the Netherlands. It applied to proceedings before the 'European' state courts, next to a set of much more compact 'Native Regulations', dating from 1848 though later revised ${ }^{18}$, for use in the state 'Native' courts as far as Java was concerned. ${ }^{19}$

With the abolition of the pre-war legal pluralism, as far as its public law aspects were concerned, and the resulting uniformation of the courts, the revised 'Native Regulations' were taken to become the directly applicable and principal rules of (penal and civil) procedure in the unified state court system, under the name of 'Revised Indonesian Regulations' (hereinafter RIB, after its Indonesian designation). It is, however, established Indonesian legal practice that RV provisions are being used by the courts supplementary to the RIB whenever the latter does not provide adequately for the matter at hand and when application of the RV would serve the realization of the substantive law.

\section{JURISDICTION}

\subsection{The notion of jurisdiction}

The notion of jurisdiction, within the meaning of the internationally recognized adjudicatory power of Indonesian courts as organs of the Indonesian state, plays no effective role in the Indonesian law or doctrine of international civil procedure. The issue is avoided or, rather, denied by focusing on domestic jurisdictional rules.

\footnotetext{
${ }^{17}$ RV Art. 641.

${ }^{18}$ NISG 1848 No. 16, subsequently revised: NISG 1926 No. 559 and NISG 1941 No. 44.

${ }^{19}$ A separate but similar set of rules was applicable for the 'Native' state courts in the 'Outer Possessions'.
} 


\subsection{The exercise of jurisdiction}

\subsubsection{General}

\subsubsection{Forum}

According to the RIB as applied by the Indonesian courts, a civil law suit is to be filed with the court of the defendant's habitual residence (in Dutch: woonplaats; in Indonesian: tempat tinggal): 'actor sequitur forum rei' ${ }^{20}$ In case the defendant is a legal entity, the place of habitual residence is to be substituted by the place of the entity's legal seat (which is the place of incorporation or principal place of business) ${ }^{21}$ In case of more than one defendant, the plaintiff has the right to choose among the courts competent in respect of each of the defendants. ${ }^{22}$ These requirements show that the 'basis of presence' is essential. If, however, the defendant's habitual residence is unknown or if the defendant himself is unknown, the petition may by way of exception be filed with the Court of the plaintiff's residence. ${ }^{23}$

In determining the rules relating to 'international jurisdiction', Indonesian judicial practice follows the Dutch model according to which the defendant's domicile basically determines jurisdiction in international (transboundary) matters. The Indonesian court is deemed to have international jurisdiction if the defendant's residence is in Indonesia and may consequently be sued under the (domestic) forum rei rule. ${ }^{24}$

\subsubsection{Forum actoris}

As already mentioned earlier, if the defendant's habitual residence is unknown, or if the defendant himself is unknown, then the court of the plaintiff's habitua' residence is competent. This rule is also applied in transboundary cases following the RV, according to which, in case the defendant has no legal residence nor an actual residence in the country, the Indonesian court is deemed to be competent provided the plaintiff has his habitual residence in Indonesia. ${ }^{25}$

\footnotetext{
${ }^{20}$ RIB, Art. 118. The term 'habitual residence' has been used in the Hague Conventions on private international law. See the 1961 Child Protection Convention and the 1965 Adoption Convention. The term is regarded to be more factual than the English term 'domicile'. The requirement of forum rei is in line with the 1971 Hague Convention on the Recognition and Enforcement of Foreign Judgments in Civil and Commercial Matters.

${ }^{21}$ Depending on the doctrine adhered to. See S. GAUTAMA, 7 Hukum perdata internasional Indonesia [Indonesian Private International Law] (3d ed., 1995) Ch. 22.

${ }^{22}$ RIB, Art. 118(2).

${ }^{23}$ Ibid., Art. 118(3). Forum actoris, see infra.

${ }^{24}$ Cf. R. VAN ROOIJ and M.V. POLAK, Private International Law in the Netherlands (1987) 45. The same approach is taken in the European Convention on Jurisdiction and Execution, Art. 2. ${ }^{25} \mathrm{RV}$, Art. 99(3).
} 
Another exception to the forum rei rule is the possibility to sue before an Indonesian court non-resident aliens without a known address in Indonesia, for obligations arising from transactions concluded with Indonesian nationals. ${ }^{26}$ This mode, unknown in the RIB and applied by analogy to the RV, was in fact derived from the French Code. It is a less known exception to the forum rei rule and has been much criticized by various author ${ }^{27}$ It enables an Indonesian plaintiff to bring a foreign party without a known address in Indonesia before an Indonesian court. ${ }^{28}$ Of course the ultimate decision of the Indonesian court would not be enforceable in the foreign country where the defendant company has its legal seat, but it may be of value to bring foreign opponents to the negotiating table. ${ }^{29}$

\subsubsection{Jurisdiction to enjoin and to arrest}

The RV contains specific provisions vith regard to the filing of a suit by an alien before the Indonesian courts. Under one of these provisions the foreign plaintiff is obliged to provide 'security for costs', the so-called cautio judicatum solvi. ${ }^{30}$ The RIB does not contain rules on the matter and, according to Indonesian judicial practice as well as legal writings, the court is not obliged to order the provision of such security for costs, not in relation to foreign plaintiffs nor to foreign defendants who file a counterclaim. The rationale is that at present any plaintiff has to pay an advance for the court fees when filing a civil law suit with the state courts. Besides, the final costs which the defeated party may ultimately be ordered to pay are confined to the official court fees which are

\footnotetext{
${ }^{26}$ This possibility is also derived from the RV, Art. 100: [translated from the Dutch text] "An alien who has no permanent residence in Indonesia, or who is not even living in Indonesia, may be sued before the Indonesian court in respect of transactions with an Indonesian national, concluded in Indonesia or elsewhere". The corresponding provision in Dutch law (Art. 127 Code of Civil Procedure) has been referred to as a 'dead letter' as far as Dutch judiciary practice is concerned. See VAN ROOIJ and POLAK, op. cit. n. 24 p. 53.

${ }^{27}$ See, inter alia, L.I. DE WINTER, 'Excessive jurisdiction in private international law', 17 ICLQ (1968) 706, who classified it as having a 'chauvinistic character'. L. STRIKWERDA, in Nederlands Internationaal Privaatrecht, special issue, 1996, p. 96, observed that, internationally, forum actoris is in fact no more accepted as a proper forum. DELAUME, in American-French Private International Law (1953) 57, called it "a legal trap into which foreigners, unaware of the existence of the privilege, may fall".

${ }^{28}$ In my personal experience as a litigation lawyer this has proven to be useful. Reference may be made to the case filed against a Liberian shipping company by the Indonesian state-owned oil company Pertamina before the Central Jakarta Court in the 1970s for the annulment of overpriced tanker lease contracts between Pertamina and the Rappaport Group. The case was settled out of court.

${ }^{29}$ This was in fact what happened in the case referred to in the preceding note.

${ }^{30} \mathrm{RV}$, Art. 128: [translated from the Dutch text] "Non-resident aliens who act as plaintiff or . . . intervening party are obliged, upon request of the opposing party, . . . to provide security for costs, damages and interests for which he might be declared liable."
} 
nominal. ${ }^{31}$ Under Indonesian law the defeated party is not liable for the victorious party's lawyer's fees.

Another special aspect of proceedings involving non-residents is that the other party may always apply and obtain permission for attachment of the nonresident's assets in Indonesia. ${ }^{32}$

Depending on the subject matter of the case, provisional measures may be requested from, and ordered by the court, enjoining a party to refrain from acting in a certain way or from altering the status quo pending a decision in the case. These measures may also be ordered in transboundary cases.

\subsubsection{Jurisdiction in rem}

Claims with respect to rights to immovables fall under the jurisdiction of the court having jurisdiction at the place where the immovable is situated (in Indonesia). The RIB itself does not contain a provision to this effect, but Indonesian judicial practice follows the relevant RV rule. ${ }^{33}$

\subsubsection{Constraints on exercise of jurisdiction (forum non conveniens)}

According to the forum non conveniens doctrine, the court may refrain from exercising jurisdiction by declaring itself incompetent in the matter, despite having jurisdiction according to the criteria for international jurisdiction. This possibility for refusal to exercise jurisdiction is based on the consideration that in some cases insufficient connections with the legal sphere to which the court belongs might exist.

The doctrine may thus practically serve as a general exception to the international jurisdiction of the court. It is well-known in Anglo-American private international law but much less in the continental European systems. Consequently the doctrine seems to flourish in countries like Singapore and Malaysia, ${ }^{34}$ while there is no comparable rule nor praxis in Indonesia.

\subsection{Forum selection}

The Indonesian law of civil procedure recognizes the freedom of choice of forum. This implies the recognition of the jurisdiction of the court chosen by

\footnotetext{
${ }^{31}$ RIB, Art. 182.

${ }^{32} \mathrm{RV}$, Art. 757.

${ }^{33} \mathrm{RV}$, Art. 99(8).

${ }^{34}$ See e.g., Justice JUdTH PraKaSh's paper, 'Forum non conveniens and lis alibi pendens', presented at the 8th Singapore Conference on International Business Law on Current Legal Issues in International Commercial Litigation, 1996. Justice PRAKASH quoted the House of Lords in Spiliada v. Cansulex Ltd, (1986) 3 All ER 843, and outlined that Commonwealth jurisdictions such as Singapore, Malaysia, New Zealand and Canada have fully adopted and applied the doctrine, while Australia has some reservations.
} 
the parties. Such choice of forum can, for example, be found in many standard maritime transport contracts (bills of lading) of Indonesian shipping companies where it sometimes appears next to a clause on choice of applicable law. Indonesian judicial practice shows that Indonesian courts have no problem in exercising jurisdiction that has been conferred on them by the parties by way of choice of forum.

A choice of forum without a choice of applicable law implies a choice for the lex fori. In Indonesian legal practice transnational loan agreements often contain a clause opting for the forum of the foreign lender, thus extricating the Indonesia-based borrower from the Indonesian courts and Indonesian law. The present author considers a choice of this kind completely valid, although no court decisions are available on the question yet. On the other hand, the Jakarta District Court decided that it had no jurisdiction in a case in which the parties had made an express choice of Singapore law but no choice of forum. ${ }^{35}$ This was, in my opinion, a wrong decision. A choice of law should be regarded as something separate and different from a choice of forum. ${ }^{36}$

Just like it often occurs that transnational loan agreements contain a choice of forum clause, they sometimes contain a choice of law clause without a choice of forum. In a loan agreement between the Jakarta branch of a foreign bank and a local Indonesian company Japanese law was chosen by the parties as the applicable law. The Jakarta District Court in 1982 correctly took cognizance of the case while ruling that the choice of law should be respected ${ }^{37}$ in spite of an exception raised by the foreign defendant that the court should declare itself incompetent since the parties had opted for foreign law. In another case involving Singapore citizens as the plaintiffs and a Jakarta branch of a foreign bank as the defendant, the Central Jakarta District Court also correctly refused the defendant's contention that, since Singapore law was chosen by the parties, the Singapore court should have jurisdiction in the matter. The Court held itself competent. ${ }^{38}$

\footnotetext{
${ }^{35}$ Case No. 560/1982G. In appeal, however, the Jakarta High Court has not upheld the lower court's decision.

${ }^{36}$ See GaUtama, op. cit. n. 21.

${ }^{37}$ P.T. Indokaya Nissan Motors $v$. Marubeni Corporation, Central Jakarta District Court, Case 560/1982/Pdt. G of 11 October 1983; (in appeal) Jakarta High Court, No. 18/1984/Pdt. of 22 May 1984; (in cassation) Supreme Court No. 2820K/Pdt. 1984 of 27 February 1986. Commented on in S. Gautama, op. cit. n. 5, Vol. 6, case No. 4. The recognition of the choice of law as the expression of the intention of the parties is established case law in the field of inter-personal law in Indonesia.

${ }^{38}$ Case No. 325/1982G. Since there was, according to the Court, no difference between Singapore and Indonesian law in respect of the matter, it chose to apply the Indonesian Civil Code.
} 


\subsection{Lis alibi pendens}

This stay of action on grounds of pending proceedings between the same parties on the same subject matter before another court is known in the Indonesian law of civil procedure, though only in the $\mathrm{RV}^{39}$ and not in the RIB. In my opinion the RV provision should be applied in transboundary cases too, but there is neither directly applicable legislation nor a court decision available on the matter.

\subsection{Immunities}

Following Article 13A of the Dutch 'General Provisions of Legislation' (abbreviated $\mathrm{AB}$ after its Dutch name Algemene Bepalingen van Wetgeving), Article $22 \mathrm{~A}$ of the Indonesian version of the General Provisions stipulates that "[t]he jurisdiction of the Indonesian courts, as well as the enforcement of court decisions [. . .] are limited by the exceptions contained in the law of nations". ${ }^{40}$

Under this provision it is suggested that foreign states and state organs, when acting iure imperii, are to be regarded as having immunity precluding the Indonesian courts to sit in judgment over them. But if they act iure gestionis in daily civil undertakings, such as renting a house, it should be possible to sue them before Indonesian civil courts.

Yet, in its attitude towards the outside world Indonesia used to adhere to the doctrine of absolute immunity. ${ }^{41}$ This has become apparent in the attitude of state organs in judicial practice in Indonesia towards foreign states. In cases concerning non-payment of rent by foreign embassies or consulates, or of compensation due for returning leased houses in a bad state etc. (i.e. acts jure gestionis), where a foreign state refuses to appear before the court, the court channels its summons through the Indonesian Ministry of Foreign Affairs. In practice this Ministry appears reluctant to service the summons under the impact of the doctrine of absolute immunity. ${ }^{42}$ In case the foreign embassy, even though

\footnotetext{
${ }^{39}$ RV, Art. 134.

${ }^{40}$ The provision was inserted into the 19th century $A B$ in the Netherlands in response to a Dutch court decision during the First World War convicting the German state for tort. In accordance with the concordance principle, the article was inserted in the Indonesian AB in 1918.

${ }^{41}$ See e.g., Yuan Ismael \& Company Inc. v. Government of the Republic of Indonesia, [1955] AC 72 , before the Hongkong courts in 1954; the series of cases before various foreign courts concerning the nationalization of Dutch tobacco plantations in Indonesia during the struggle for the return of Western New Guinea (now: Irian Jaya); and several other cases.
}

42 For these practices, see S. GAUTAMA, Aneka masalah hukum perdata internasional [Miscellaneous Problems of Private International Law], 1985. See also, for the doctrine of immunity and the 'act of state' doctrine, YUDHA BHAKTI ARDINISASTRA, Perkembangan penerapan imunitas kedaulatan negara dalam penyelesaian perkara diforum pengadilan - Studi perbandingan atas praktek Indonesia diforum pengadilan asing [The Development of the Application of State Immunity in the Settlement of Disputes before the Court - a Comparative Study of the Indonesian 
it was properly served, still refuses to appear, the Jakarta court used to declare itself incompetent for lack of jurisdiction. ${ }^{43}$

\section{SERVICE OF PROCESS}

According to the RIB, a law suit starts with the filing of a request or petition by the plaintiff at the court of the defendant's habitual residence. ${ }^{44}$ In case of a defendant abroad, the service is channelled through the Foreign Ministry which delivers the summons through the embassy or consulate in the country of residence or seat of the defendant. The foreign party is as a rule represented by an Indonesian attorney who is given a legalized power of attorney. The power of attorney must not be worded in general terms, but should specify the name of the other party in the case, a short description of the case and, whenever possible, the registration number of the case at the Indonesian court.

\section{TAKING OF EVIDENCE ABROAD}

There are no special provisions in the RIB, nor in the RV, with regard to the taking of evidence abroad. Indonesia, however, has concluded a treaty with Thailand on the subject. ${ }^{45}$ Although the treaty bears the broader title of judicial cooperation, it deals primarily with cooperation between the courts of the two countries concerning the taking of evidence by way of 'letters of request'. Indonesian courts may request the hearing of witnesses domiciled in Thailand by a Thai court by way of 'rogatory commission'.

So far no such a request has yet been made by the Thai judiciary to its Indonesian counterpart, nor the other way around. Nonetheless, ultimately this bilateral treaty will serve as a starting point and model for closer multilateral judicial cooperation between the states in the ASEAN region.

\section{RECOGNITION AND ENFORCEMENT OF FOREIGN JUDGMENTS}

In dealing with this subject it may be useful to note the distinction between recognition and enforcement of foreign judgments. Enforcement is something more profound than recognition and is broader in scope. It requires some

\footnotetext{
Practice before Foreign Courts], doctoral dissertation, Pajajaran University, Bandung, 1995.

${ }^{43}$ In some cases the defendant foreign state subjected itself voluntarily to the jurisdiction of the Indonesian court. See e.g. Supreme Court 16 July 1974 in case No. 635/Sip/1973, in S. GAUTAMA, op. cit. n. 5 Vol. 7 (1993), case No. 4, with comments by the author.

${ }^{44}$ RIB, Art. 118.

${ }^{45}$ For this Convention see S. GAUTAMA, Indonesia dan Konvensi-konvensi hukum perdata internasional [Indonesia and Conventions on Private International Law], rev. ed. 1996.
} 
positive action by the court and organs of the executive branch of government. Recognition, on the other hand, is more passive and does not require action by the court. Therefore, states may be more liberal in recognizing foreign judgments than enforcing them. ${ }^{46}$

Contrary to its adherence to the 1958 New York Convention on the Recognition and Enforcement of Foreign Arbitral Awards, Indonesia has so far not concluded any treaty for the recognition and enforcement of foreign court judgments.

In principle the situation in Indonesia with regard to the status of foreign judgments is quite clear: they are as a rule not recognized and cannot be enforced in Indonesia. There are no directly applicable written rules, as the RIB does not contain provisions on the matter, but the non-enforceability of foreign judgments is explicitly stated in Article 436 of the RV which reads:

"Except in cases referred to in Article 724 of the Commercial Code no judgments handed down by foreign . . . courts can be enforced in Indonesia. The cases may be tried afresh and finalized by the court in Indonesia.

In case of the above exception, the judgment of the foreign court shall not be enforced before a leave for enforcement (exequatur) has been obtained . . . [from the Indonesian court]."

This article, or at least its substance, is still being applied.

Although a foreign judgment is not directly enforceable, it is by no means totally worthless: it serves as prima facie evidence in the new case to be filed in Indonesia. ${ }^{47}$ Moreover, the classical view of non-enforceability has undergone a tempering/moderating development. As a result the court is practically free to determine, in each specific case, whether and to what extent the foreign judgment is accepted. Judgments containing condemnatory money payments are not enforceable, but declaratory decisions are usually recognized.

Meanwhile there are proposals in the context of national law development by the National Law Development Institute ${ }^{48}$ towards giving positive effect to, and allowing enforcement of, foreign judgments. ${ }^{49}$ On another aspect, the present author has argued for a treaty for the harmonization of enforcement and recognition of foreign judgments in the ASEAN countries. ${ }^{50}$ To standardize the

\footnotetext{
${ }^{46}$ Especially in Anglo-Saxon literature due attention is paid to the difference between the two concepts.

${ }^{47}$ See B.A. CAFFREY, Enforcement of Foreign Judgments (a study for Lawasia, 1985) 67 et seq., for the different systems in the ASEAN region: the 'common law method' and the 'legislative method' based on the 'obligation theory' (inter alia, Singapore); the 'Indian method'; the 'Japanese method' based on the German system; the 'evidentiary method' (Indonesia, Thailand); the 'appeal method' (Philippines, modeled on the US system).

${ }^{48}$ An autonomous Directorate-General of the Ministry of Justice.

${ }^{49}$ Reference is made here to Art. 76 of the draft for a new Civil Procedure Code which reads as follows: "Judgments of a court belonging to a different legal sphere and decisions of foreign courts, of which enforcement is requested, may be enforced under the present Part of the code in accordance with the applicable law and on order of the Supreme Court."

50 'Recognition and enforcement of foreign judgments and arbitral awards in the ASEAN region',
} 
existing different rules and procedures it was suggested to have an ASEAN Convention along the lines of the European Convention of $1968^{51}$ and the 1971 Hague Convention on the Recognition and Enforcement of Foreign Judgments in Civil and Commercial Matters. ${ }^{52}$

The tendency not to enforce foreign judgments is in line with the principle of territorial sovereignty. Under this principle judgments cannot be automatically enforced in the territory of another state, and the principle of 'judicial sovereignty' is closely connected with it. ${ }^{53}$ Moreover, the non-enforceability of foreign judgments in Indonesia may also be considered as being in accordance with Article 22a of the 'General Provisions of Legislation' ${ }^{54}$ For foreign judgments to qualify for enforcement in other states, there must, as a rule, be a treaty between the state of enforcement and the state where the judgment has been pronounced rendering each other's judgments reciprocally enforceable in the same way as judgments emanating from national courts. So far Indonesia has concluded no such execution treaty.

The above-mentioned exception to ron-enforceability in Article 436 of the RV refers to foreign judgments dealing with 'general average' compensation in the law on maritime transport and will not be elaborated here because of its specific nature.

Does the doctrine on the non-enforceability of foreign judgments apply to all kinds of judicial decisions or is a differentiation to be made between types of judgments, such as condemnatory and declaratory ones, and decisions concerning the personal or family law status of a person? There is no consensus of opinion on this matter.

Foreign judgments of a declaratory nature, such as those dealing with the validity of a marriage or a divorce, or the validity of proprietary rights (ownership) to goods expropriated from the original owner, will as a rule be recognized by the Indonesian courts. ${ }^{55}$ The same is the case with constitutive

paper presented at the 5th ASEAN Law Association Conference at Denpasar, Bali, 1989. The idea obtained the support of other scholars. See PEARLIE M.C. KoH, 'Foreign judgments in ASEAN - a proposal', 45 ICLQ (1996) 844. See also S. GAUTAMA, 8 Hukum perdata internasional Indonesia [Indonesian Private International Law] (2nd ed. 1987) 807 et seq.

${ }^{51}$ This Convention directly distributes jurisdiction amongst the courts of the EEC (now European Union) member states. The success of this Convention is primarily due to the fact that jurisdictional issues of the different courts are clearly outlined. See B.A. CAFFREY, op. cit. n. 47 p. 24.

${ }^{52}$ The text of this Convention is included in Recueil des Conventions de La Haye de Droit International Privé (1951-1988), edited and published by the Permanent Bureau of the Hague Conference on Private International Law, The Hague.

${ }^{53}$ The Supreme Court of the Netherlands said in an early decision of 31 January 1902: "Since a judge acts as a state organ, the scope of his decisions is limited to the territory over which the state authority extends; outside that territory, they are only binding in such a manner and under such prerequisites as the competent authority in each state involved determines." Weekblad van het Recht [Law Weekly] No. 7717.

${ }^{54}$ See supra, section 2.5 .

${ }^{55}$ This is in line with the 'Act of state' doctrine. Cf. SUdARGo GaUtama (Gouw GIOK SiONG), Segi-segi hukum internasional pada nasionalisasi di Indonesia [International Law Aspects of 
decisions which create a certain legal situation or relationship, e.g. decisions concerning the annulment of a contract, the termination of a marriage, the appointment of a guardian, adoption, etc. Declaratory decisions do not need any enforcement by Indonesian courts as they merely affirm rights and duties between the parties. It is natural that these, so-called 'status decisions', are recognized rather easily because they only require the adjustment of the registers of the Civil Registry by administrative authorities. When status decisions of foreign courts deal with persons of Indonesian nationality, they must not only be rendered by a competent court but must also comply with Indonesian private international law rules applicable to the facts of the case concerned, in order to be eligible for recognition and enforcement. Foreign divorce judgments involving Indonesian nationals, for example, will only be recognized if Indonesian law was applied and Indonesian grounds of divorce were duly observed. Similarly, it may be assumed that foreign guardianship decisions concerning Indonesian minors and foreign adoption decisions involving Indonesian nationals would only be recognized if Indonesian law was applied. The reason of all this is that under Indonesian private international law the nationality principle is adhered to in matters of personal status. ${ }^{56}$

Finally, the general limit set to the discretion of the Indonesian court to recognize or enforce a foreign judgment is, of course, that this judgment must not be contrary to Indonesian 'international public policy'.

The fact that foreign judgments cannot be automatically enforced in Indonesian territory is a matter that has not been sufficiently taken into consideration by foreign parties to contracts with Indonesian counterparts. We often see that in such contracts a choice of jurisdiction is made in favour of a foreign court, usually that of the country of the foreign party's domicile. The foreign party and his counselling lawyer are usually of the opinion that it is to their advantage to be entitled to sue the Indonesian counterpart before the courts of the chosen jurisdiction. They appear, however, to be less aware that a favourable decision obtained from the foreign court cannot be enforced in Indonesia where the assets of the Indonesian party, as a rule, are located. Thus the value of a foreign decision is different from a decision obtained through an Indonesian court, and it may well be that the foreign party is only losing time and money by instituting the case before a foreign court.

Nationalization in Indonesia] (1960).

${ }^{56}$ Art. 16 of the General Provisions of Legislation cf. supra section 2.5. 


\section{ARBITRATION}

\subsection{The law on arbitration}

The regulation of arbitration in Indonesia is to be found in Title One of Book III of the RV. The Articles 615-651 are similar to those of the Dutch Code of Civil Procedure before the latter's revision, which were in turn based on the [former] French Code. Under the colonial regime the articles were meant to apply only to those persons who were subject to 'European' or 'Western' civil law. The RIB does not contain provisions on the matter. Consequently, in present practice the RV provisions are applied to relationships among persons belonging to any group of the population. As far as the application to members of the majority group of indigenous Indonesians is concerned, recourse is sometimes taken to the presumption that, whenever such a person claims a right to submit to arbitration, he is deemed to have subjected himself voluntarily to the 'Western, European' law.

Since the applicability of the RV and its articles is based on the Transitory Provisions of the Constitution, and in view of the proviso that the existing law may not be contrary to the Constitution, Indonesian courts are in fact free to set aside or to reshape any of the arbitration rules of the RV whenever they are regarded no longer suitable in an independent Indonesia. Article 617(2), for example, prohibits the appointment of women as arbitrators. In independent Indonesia, however, women are treated on an equal footing with men and, consequently, the relevant provision is considered to be no more valid. ${ }^{57}$

At present the Indonesian Ministry of Justice has completed a draft of a new arbitration law $^{58}$ which is now scheduled for submission to Parliament.

Finally, some specific laws provide for arbitration as a means of dispute settlement. For instance, the Foreign Capital Investment Law of 1967 and the 1974 Foreign Investment Law inter alia provide for arbitration in case of disagreement on the amount of compensation in case of nationalization. ${ }^{59}$

\footnotetext{
${ }^{57}$ Supreme Court Circular Letter 1963 No. 3.

${ }^{58} \mathrm{An}$ academic draft was submitted by the present author upon request. It formed the basis for the official draft which has now been accepted by various government departments. For the successive drafts see S. GAUTAMA, Aneka hukum arbitrase [Miscellaneous Aspects of Arbitration Law] (1996). In 1994 another academic draft was submitted by a committee of economic law experts sponsored by US AID under the so-called 'Elips project'.

${ }^{59}$ International instruments may also provide for arbitration. As far as Indonesia adheres to such instruments, the possibility of arbitration offered may be relevant for Indonesia. See e.g. the Convention for the Settlement of Investment Disputes between States and Nationals of Other States, 1965 (ICSID Convention); and the following case decided by ICSID arbitration: Amco Asia Corp. and others $v$. The Republic of Indonesia, 89 International Law Reports 366 et seq. and, as to the latest decision in this case (of 3 December 1992): S. GAUTAMA, Arbitrase Bank Dunia terhadap penanaman modal asing di Indonesia dan yurisprudensi Indonesia dalam perkara hukum perdata internasional [World Bank Arbitration on Foreign Investment in Indonesia and Indonesian Case Law in the Field of Private International Law] (1994).
} 


\subsection{The practice of arbitration}

While arbitration was frequently resorted to in the pre-independence period, later the number diminished significantly. At present, however, the importance of arbitration as a way of settlement of disputes is gradually increasing again in the field of economic transactions, particularly in respect of international commercial contracts. The foreign party often still feels uneasy before the national courts of his Indonesian contract partner and prefers to avoid the (in his eyes) biased national court of his opponent. In this situation arbitration is the most suitable form of dispute settlement. Nowadays it is in fact standard procedure in most contracts between Indonesian and foreign parties.

The Indonesian Chamber of Commerce has set up its own National Indonesian Arbitration Institute (BANI after its Indonesian name 'Badan Arbitrase Nasional Indonesia'. Arbitration clauses in favour of arbitration outside Indonesia refer to various arbitration tribunals and rules, such as the International Chamber of Commerce in Paris, the London Arbitration Court, and Tokyo. Increasingly reference is made to the UNCITRAL arbitration rules and the Regional Arbitration Centre in Kuala Lumpur under the auspices of the AsianAfrican Legal Consultative Committee.

The Supreme Court has emphasized the obligation of courts to give effect to arbitration clauses by rendering courts incompetent in such cases. In Ahju Forestry Comp. Ltd. v. P.T. Balikpapan Raya a dispute had arisen between a Korean company and its Indonesian partner concerning their joint venture company. Upon the request of the Indonesian party the North Jakarta District Court regarded itself competent by pronouncing on the validity of the transfer of the company's management, notwithstanding an arbitration clause. On appeal, the Jakarta Appeal Court affirmed the lower court's decision. The Supreme Court, however, gave effect to the arbitration clause and declared that the Indonesian court had no jurisdiction. ${ }^{60}$ The same happened in P.T. Metropolitan Timbers v. P.T. Gapki Trading Comp. ${ }^{61}$ where the dispute was between a foreign contractor engaged in the exploitation of a timber forestry concession and its Indonesian counterpart.

\subsection{The enforcement of foreign arbitral awards}

For the question of enforcement a distinction is to be made between whether or not a treaty on the matter applies to the case. Two multilateral treaties are relevant for the Indonesian situation: the 1927 Geneva Convention for the Execution of Foreign Arbitral Awards (in conjunction with the 1923 Geneva

\footnotetext{
${ }^{60}$ Supreme Court 8 February 1982, No. 2924K/Sip/1981, in Himpunan putusan Mahkamah Agung tentang arbitrase internasional [Collection of Supreme Court Decisions concerning International Arbitration] (1988).

${ }^{61}$ Supreme Court 30 September 1983, case No. 2225K/Sip/1976, ibid.
} 
Protocol on Arbitration Clauses) and the 1958 New York Convention on the Recognition and Enforcement of Foreign Arbitral Awards.

As to the 1927 Geneva Convention and the 1923 Protocol, the Netherlands were a party to the Convention and Protocol and extended their application to Indonesia on 28 April $1933 .{ }^{62}$ The Supreme Court, in a decision of 1984, considered the question whether Indonesia was bound by the Convention after its attainment of independence. ${ }^{63}$ It held that, in spite of the application of the Convention to Indonesia in 1933 and in spite of a devolution provision in the Indonesian-Dutch Agreements on the occasion of the Dutch recognition of Indonesian independence in 1949, new principles of international law regarding state succession had emerged since World War II according to which Indonesia was not bound by pre-independence treaties.

In the same decision of 1984, the Supreme Court scrutinized whether the 1958 Convention was to be applied by the Court. Acknowledging that Indonesia had acceded to the Convention which came into effect for it on 7 October 1981, the Supreme Court held that:

“ . . . in accordance with Indonesian practice it is necessary for the government to introduce implementing legislation. Such legislation must be observed both in case of a request to the District Court for the enforcement of a foreign award and in case of a direct request to the Supreme Court for the determination as to whether the award is contrary to Indonesian public policy".

The court concluded that pending such implementing legislation the Indonesian courts cannot order the enforcement of foreign arbitral awards on the basis of the Convention.

This was a disappointing decision since a formal implementing regulation is not normally required in respect to treaties. It is suggested that the enforcement of foreign awards should be effected in the same manner as domestic arbitral awards, and in fact along the lines of the enforcement of a normal court decision, through the District Court of the defendant's place of habitual residence. This is essentially the way prescribed by Article 639 of the RV. My conclusion is, therefore, that a foreign award, enforcement of which is sought under the New York Convention, can be executed even without implementing legislation. This does not imply an automatic enforcement, as recognition and enforcement may be refused by the Indonesian court on one of the five grounds listed in

\footnotetext{
${ }^{62}$ NISG 1933 Nos. 131 and 132.

${ }^{63}$ Cf. S. GAUTAMA, Capita selecta hukum perdata internasional (1974) 97; R. HORNICK and SIDIK SURAPUTRA, 'Beberapa masalah hambatan terhadap pelaksanaan perwasitan internasional di Indonesia' [Some problems obstructing the enforcement of international arbitration in Indonesia], Hukum dan Pembangunan [Law and Development; Journal of the Faculty of Law of the University of Indonesia] (1986) 283 and 289; H. Gunanto, "Implementing regulations for the 1958 New York Convention on the recognition and enforcement of foreign arbitral awards in Indonesia", 1 AsYIL 151-155. The decision was of 29 November 1984, case No. 2944 K/Pdt/1983 in Navigation Maritime Bulgare $v$. P.T. Nizwar.
} 
Article $\mathrm{V}(1)$ of the Convention or one of the two grounds stated in Article $\mathrm{V}(2)$.

The Supreme Court's decision of 1984 is being criticized especially because of its attitude towards the applicability of the New York Convention. The question about the Geneva Convention has become rather theoretical since the Convention's replacement by the New York Convention and the almost worldwide adherence to the latter. Later the Supreme Court took measures to fill the suspected gap in legislation, by issuing Supreme Court Regulation No. 1 of 1 March 1990.

The courts will always refuse enforcement of the foreign award if it is found to be contrary to Indonesian public policy. However, no clear criteria exist for this notion in regard to arbitral awards. In the case of E.D. and F. Mann (Sugar) Ltd. v. Yani Harjanto ${ }^{64}$ the Supreme Court had issued a fiat exequatur to the foreign sugar firm Mann, for the enforcement of a London arbitration award, in accordance with the applicable rules as embodied in a Supreme Court Regulation of 1990 . Yet, in a subsequent decision the Supreme Court denied further enforcement of the award in Indonesia for being contrary to Indonesian public policy (ketertiban umum). The decision was based on grounds that the sugar sale contract which contained the arbitration clause was null and void for being in violation of an Indonesian government regulation under which a certain government body was designated as the sole body entitled to import sugar into Indonesia, thereby excluding private individuals like YANI HARJANTO.

${ }^{64}$ Supreme Court case No. 1203/Pdt/1990 of 14 December 1991, in conjunction with Central Jakarta District Court case No. 736/Pdt/G/1988/PN Jakarta Pusat, and Jakarta High Court case No. 485/Pdt/1989/PT DKI. Commented on in S. GaUTAMA, op. cit n. 5 Vol. 6 case No. 2. 